\title{
Seasonal comparison of Calanoides acutus and Calanus propinquus (Copepoda: Calanoida) in the southeastern Weddell Sea, Antarctica
}

\author{
Sigrid B. Schnack-Schiel, Wilhelm Hagen*, Elke Mizdalski
}

Alfred-Wegener-Institut für Polar- und Meeresforschung, W-2850 Bremerhaven, Germany

\begin{abstract}
The herbivorous Antarctic copepods Calanoides acutus and Calanus propinquus were studied for seasonal differences in life cycles in the southeastern Weddell Sea in January/February 1985 and in October/November 1986. During late winter/early spring older stages of $C$. acutus were concentrated below $500 \mathrm{~m}$. Males had reduced mouthparts and were only found in October/November in deep waters where mating occurred. Females with semiripe and ripe gonads migrated to the surface in November to spawn. Their ascent coincided with an increase in swimming and respiration activity. In summer the majority of $C$. acutus occurred above $200 \mathrm{~m}$ and the density increased dramatically as the new cohort hatched. Copepodite stage CV and females in the surface layers had large lipid depots by the end of January, mainly wax esters. They seem to start their descent by mid February. C. propinquus also occurred in deeper waters in late winter/early spring, but above $500 \mathrm{~m}$. Males had well-developed mouthparts and were found in small numbers throughout both investigated periods. No great changes in activity were observed from late winter to summer. The summer population was concentrated in the upper $100 \mathrm{~m}$. As for $C$. acutus there was a dramatic increase in abundance of $C$. propinquus from January to February. The lipid content of $C V$ stages and females doubled from January to February and reached similar maximum values at least $3 \mathrm{wk}$ later in the season than $C$. acutus. The lipids of $C$. propinquus consisted mainly of triacylglycerol, a very unusual storage lipid class in polar calanoid copepods. C. acutus and C. propinquus seem to represent different life histories: the wax-esteraccumulating $C$. acutus overwinters in a resting stage in deeper waters while the triacylglycerol-storing $C$. propinquus may feed and reproduce over a more extended period than $C$. acutus.
\end{abstract}

\section{INTRODUCTION}

Calanoides acutus and Calanus propinquus are dominant large copepods in Antarctic waters (e.g. Ottestad 1932), with a circumpolar distribution ranging from the Antarctic continent to the Antarctic Convergence (Ottestad 1936, Andrews 1966). Both species perform ontogenetic vertical migrations, and inhabit deeper water layers during winter and surface waters during summer (e.g. Voronina 1972, Voronina et al. 1978). These migrational patterns are related to the pronounced seasonality of the Southern Ocean. During the short summer the phytoplankton bloom supplies plenty of food for herbivorous copepods in epipelagic waters, and they can rapidly accumulate large lipid depots in their oil sacs (Lee et al. 1971, Sargent \&

- Present address: Institut für Polarökologie, Universität Kiel, W-2300 Kiel, Germany
Henderson 1986, Hagen 1988). These energy reserves may then be utilized during winter when food is scarce and for reproduction, as reviewed by Båmstedt (1986).

According to Voronina's asynchrony hypothesis (1978) late copepodite stages (CIV and CV) of both species successively migrate to the surface in spring, moult to adulthood and mate in the upper $200 \mathrm{~m}$. The offspring (copepodite stages CI and CII) remain at the surface during the feeding and growth period. At the end of summer, stages CIII and CIV start to descend below $500 \mathrm{~m}$ to overwinter. Marin (1988) opposed this asynchrony hypothesis and suggested independent life cycles for Calanoides acutus and Calanus propinquus. He proposed that $C$. acutus mates in deep water layers and the fertilized females migrate to the surface to spawn in spring. Calanus propinquus, however, ascends as copepodite stage $\mathrm{V}$ and mating occurs in surface layers. Marin (1988) postulated that part of the C. propinquus population remains in surface waters during winter. 
There are only sporadic studies on copepods from high Antarctic waters like the Weddell Sea and the Ross Sea (e.g. Kaczmaruk 1983, Hopkins 1987, BoysenEnnen \& Piatkowski 1988, Fransz 1988), and especially data on seasonal variability are scarce (Hubold \& Hempel 1987). Our studies were carried out during 2 Antarctic expeditions in January/February 1985 (summer) and in October/November 1986 (late winter/early spring). One main objective was to highlight major seasonal differences in abundance, vertical structure and age composition of Calanoides acutus and Calanus propinquus in the eastern Weddell Sea. In addition, feeding experiments, respiration measurements and lipid analyses were carried out to obtain information on the physiological state of the investigated species.

\section{METHODS}

During 2 expeditions with RV 'Polarstern' zooplankton was sampled in the southeastern Weddell Sea using a multiple opening/closing net (Weikert \& John 1981) with $100 \mu \mathrm{m}$ mesh size. The net was towed vertically at 0.5 to $1.0 \mathrm{~m} \mathrm{~s}^{-1}$ and sampled 5 successive depth layers from near the bottom or $1000 \mathrm{~m}$ depth to the surface. At one station in February 1985 (\# 334) zooplankton sampling was carried out down to $2500 \mathrm{~m}$ depth. In this paper only offshore stations (water depth $>1000 \mathrm{~m}$ ) with $1000 \mathrm{~m}$ sampling depth are considered (Table 1, Fig. 1). The filtered volume was calculated by multiplying the vertical distance of the tow with the
Table 1. List of multinet stations (D: day; $N$ : night; DA: dawn; DU: dusk)

\begin{tabular}{|ccccc|}
\hline $\begin{array}{c}\text { Stn } \\
\text { no. }\end{array}$ & Date & $\begin{array}{c}\text { Depth } \\
(\mathrm{m})\end{array}$ & $\begin{array}{c}\text { Time of } \\
\text { day }\end{array}$ & $\begin{array}{c}\text { Start } \\
\text { (h; UTC) }\end{array}$ \\
\hline 512 & 17 Oct 1986 & 3575 & $\mathrm{~N}$ & $00: 20$ \\
513 & 18 Oct 1986 & 4211 & D & $10: 40$ \\
514 & 18 Oct 1986 & 3050 & DU & $21: 40$ \\
516 & 19 Oct 1986 & 1675 & D & $13: 55$ \\
562 & 03 Nov 1986 & 1114 & D & $17: 40$ \\
565 & 04 Nov 1986 & 3125 & DA & $03: 50$ \\
570 & 05 Nov 1986 & 3220 & DA & $02: 35$ \\
604 & 17 Nov 1986 & 3253 & DU & $21: 05$ \\
607 & 18 Nov 1986 & 1732 & D & $09: 30$ \\
611 & 20 Nov 1986 & 2891 & D & $11: 55$ \\
614 & 21 Nov 1986 & 3079 & DA & $01: 55$ \\
618 & 22 Nov 1986 & 1133 & D & $16: 15$ \\
623 & 24 Nov 1986 & 1538 & DU & $23: 22$ \\
278 & 29 Jan 1985 & 1976 & D & $14: 30$ \\
279 & 29 Jan 1985 & 2783 & D & $18: 15$ \\
332 & 15 Feb 1985 & 1965 & D & $14: 10$ \\
333 & 15 Feb 1985 & 2782 & D & $17: 19$ \\
334 & 15 Feb 1985 & 3427 & DU & $20: 20$ \\
& & & & \\
\hline
\end{tabular}

multinet's mouth area $\left(0.25 \mathrm{~m}^{2}\right)$, assuming $100 \%$ filtering efficiency. The samples were preserved in $4 \%$ buffered formalin. For detailed descriptions of the biological and oceanographic programme of the 2 'Polarstern' cruises see Hempel (1985) and SchnackSchiel (1987).

Abundance was normally calculated from the entire

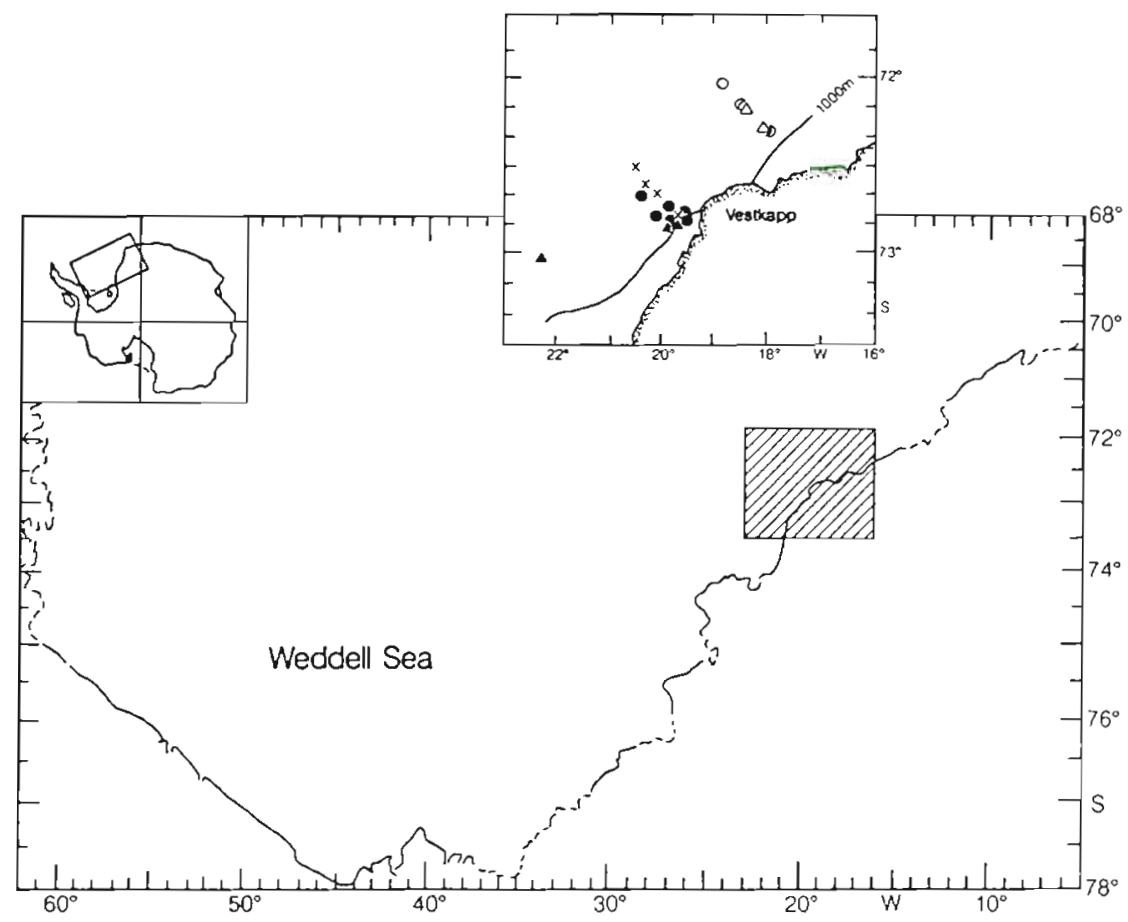

Fig. 1. Sampling area in the southeastern Weddell Sea and position of zooplankton stations. (4) 29 Jan, (O) 15 Feb 1985; (×) 17 to 19 Oct, (4) 4 to 5 Nov, (•) 17 to 24 Nov 1986 
sample. In a few cases the abundance of each stage was evaluated by counting a minimum of 30 individuals per stage from a subsample $(1 / 2$ to $1 / 10)$ using a Kott whirling apparatus. Geometric means of abundance data from offshore stations were used to compare between sampling periods. Following Huntley \& Escritor (in press) the mean population stage [S] was calculated as:

$$
[\mathrm{S}]=\frac{\mathrm{N}_{\mathrm{CI}}+2 \mathrm{~N}_{\mathrm{CII}}+\ldots+6 \mathrm{~N}_{\mathrm{CVI}}}{\Sigma \mathrm{N}}
$$

where $\mathrm{N}_{\mathrm{CI}}, \mathrm{N}_{\mathrm{CII}} \ldots \mathrm{N}_{\mathrm{CV} \text { l }}$ are the number of specimens of copepodite stages $\mathrm{CI}, \mathrm{CII}$... CVI; and $\Sigma \mathrm{N}=$ the sum of all individuals.

For experimental work copepods were sampled from the upper $300 \mathrm{~m}$ (summer) or $500 \mathrm{~m}$ (winter/spring) with a Nansen net. All experiments were carried out in a cooling container at $0{ }^{\circ} \mathrm{C}$ at dim light for 10 to $24 \mathrm{~h}$ (feeding) or for 6 to $10 \mathrm{~h}$ (respiration). Each experiment comprised 2 replicates and 2 controls without copepods. For feeding experiments, seawater was collected by membrane pump from $5 \mathrm{~m}$ depth (summer) or with Niskin bottles in the upper $100 \mathrm{~m}$ (winter/spring). The natural phytoplankton suspension was transferred into experimental $5 \mathrm{l}$ glass flasks to which actively swimming copepods were added. Copepod densities ranged between 10 and 94 specimens per flask depending on stage. Chlorophyll a concentration was analyzed spectrophotometrically at the beginning and at the end of each feeding experiment. Filtration rates were calculated after Frost (1972). For respiration experiments, 5 individuals were pipetted into $100 \mathrm{ml}$ bottles containing $0.2 \mu \mathrm{m}$ filtered, oxygen-saturated seawater. Respiration was measured by the Winkler method and rates calculated as the difference between dissolved oxygen in the control and experimental bottles before and after the experiment. During sorting under the microscope we noticed differences in swimming activity of Calanoides acutus females. Therefore, respiration measurements were carried out with females separated according to the activity levels 'non-active', 'active' and 'very active'.

For dry weight (DW) and lipid analyses copepods were carefully collected by Bongo net. Immediately after sampling, live copepods were sorted in a cooling container at $4{ }^{\circ} \mathrm{C}$. For a single sample 45 to 240 specimens of one species/stage were sorted and stored under nitrogen at $-80^{\circ} \mathrm{C}$. After determination of dry weight (lyophilized), total lipid content was measured gravimetrically (after Folch et al. 1957). Lipid class composition was analyzed according to Fraser et al. (1985) by thin-layer chromatography-flame ionization detection with an IATROSCAN. Different standard mixtures were prepared for calibration that approximated the lipid class composition of the analyzed samples. The wax ester fraction also includes sterol esters. For details see Hagen (1988). For summer samples the dry weight data of the above lyophilized samples were used. Dry weights of smaller copepodite stages were extrapolated from older stages using logtransformed length-weight relationships (after BoysenEnnen pers. comm.). Winter samples were dried at $60^{\circ} \mathrm{C}$ for $24 \mathrm{~h}$

\section{RESULTS}

\section{Population structure}

Calanoides acutus was generally more abundant than Calanus propinquus. The abundance of each species did not vary significantly ( $H$-test, $95 \%$ level) between October, November and January, but in February the abundance of both species was by far higher compared with 2 to $3 \mathrm{wk}$ earlier at the end of January (Fig. 2).

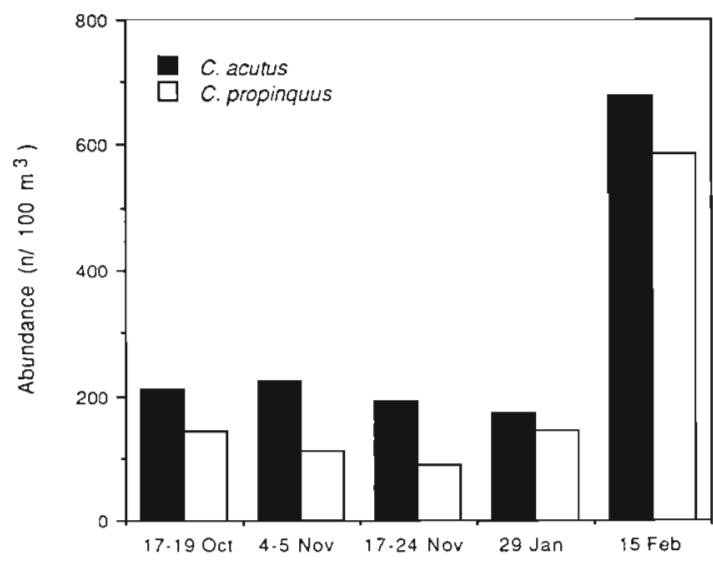

Fig. 2. Calanoides acutus and Calanus propinquus. Mean abundance of total populations (1000 to $0 \mathrm{~m}$ depth)

Older stages (mainly CIV and adults) dominated the Calanoides acutus population in October/November, while early stages (CI and CII) were absent in all samples. The bulk of the Calanus propinquus population was dominated by copepodite stages CIII, CV and females and only the first stage (CI) was not present in late winter/early spring (Fig. 3). At the end of January the population of $C$. acutus showed a bimodal stage structure in the upper $1000 \mathrm{~m}$ : CV specimens (44\%) were present from the previous year's generation, as well as offspring of the current year (CI $27 \%$ and CII $22 \%$ ). In mid-February, 2 to 3 wk later, older copepodite stages and adults were practically replaced by juveniles of the new generation (CI $56 \%$, CII $24 \%$, CV $11 \%$ ). A similar change in population structure is obvious for C. propinquus (Fig. 3)

The vertical distribution differed greatly between 

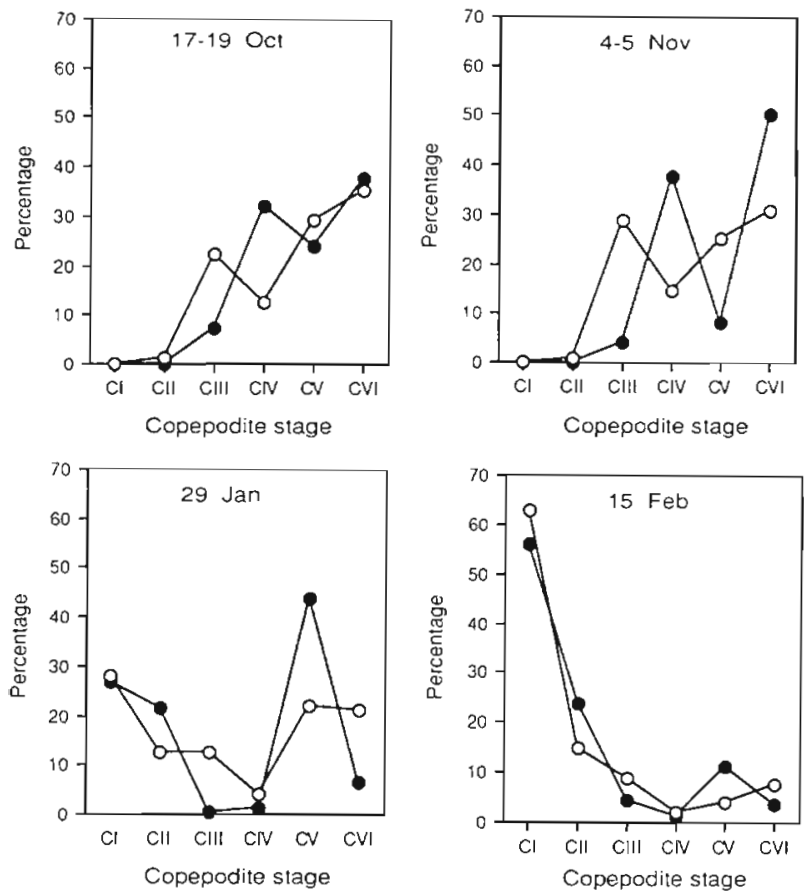

species and developmental stages. During October/ November the major part of the Calanoides acutus population was concentrated below $500 \mathrm{~m}$, except for females in mid-November (Fig. 4): from 17 to 21 November the majority of females were encountered between 500 and $200 \mathrm{~m}$; from 21 to 24 November they were found in the upper water layers (Fig. 5). Hence, only females seemed to have migrated upward during this period. Microscopic observations of the gonads showed that the state of maturity of most females was semiripe or ripe (after Runge 1985). In contrast to adults, the vertical distribution of CIV stages did not change during this time and the bulk remained below $500 \mathrm{~m}$ (Fig. 5). Males were found in higher numbers only between 1000 and $500 \mathrm{~m}$ depth and only in October/November.

In summer the majority of the Calanoides acutus population had ascended above $300 \mathrm{~m}$ (Fig. 4). At the end of January CV specimens that had overwintered were concentrated below $50 \mathrm{~m}$, whereas the offspring of the current year (CI and CII) were found above $50 \mathrm{~m}$. In February copepodite stages CI to CIII were highly concentrated in the uppermost $50 \mathrm{~m}$ (Fig. 4). There is a slight tendency for CV and females to descend. Very few specimens occurred at the only deep station between 2500 and $1000 \mathrm{~m}$ : 1 female, 5 CV, 4 CIV and $1 \mathrm{CI}$. No males were present in any of the summer samples.

The bulk of the Calanus propinquus population was found between 500 and $100 \mathrm{~m}$ in October/November (Fig. 6). No upward migration of C. propinquus was
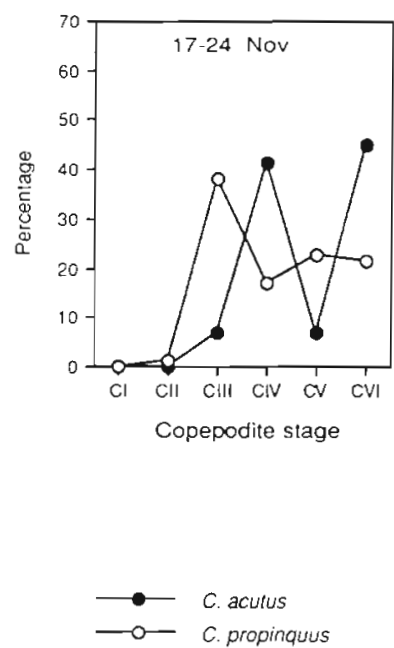

Fig. 3. Calanoides acutus and Calanus propinquus. Relative composition of developmental stages in the top $1000 \mathrm{~m}$ detected during this period. In summer the early stages $\mathrm{CI}$ and CII comprised a large proportion of the population, which was almost entirely concentrated in the upper $50 \mathrm{~m}$. Males were found in very low numbers ( $<1$ to $4 \%$ of the total population) throughout the water column during the investigated period. The low abundance of males and the high abundance of females in January was in contrast with observations for Calanoides acutus (Figs. $3 \& 6$ ). At the only deep station in February 1985 no $C$. propinquus individual occurred between 1000 and $2500 \mathrm{~m}$.

In October and the beginning of November the Calanoides acutus population consisted of significantly older stages than the Calanus propinquus population (U-test, $95 \%$ level) (Fig. 7). During this period, and integrated over the top $1000 \mathrm{~m}, \mathrm{C}$. acutus had a significantly different mean population stage [S] of 5.0, as compared to C. propinquus with 4.5 (U-test, $95 \%$ level). This difference was most pronounced in midNovember due to the beginning ascent of $C$. acutus females, while $C$. propinquus females did not show such an upward migration. In summer both species had a similarly young mean population stage in the upper $50 \mathrm{~m}$, where the bulk of both populations was concentrated. This young mean population stage reflects the dominance of the early copepodite stages of the new generation. Between 50 and $1000 \mathrm{~m}$ the mean population stage of $C$. acutus was significantly more advanced than in C. propinquus (U-test, $95 \%$ level).

Females of both species occurred in higher numbers than males (Table 2) except for Calanoides acutus in 


\section{Calanoides acutus}

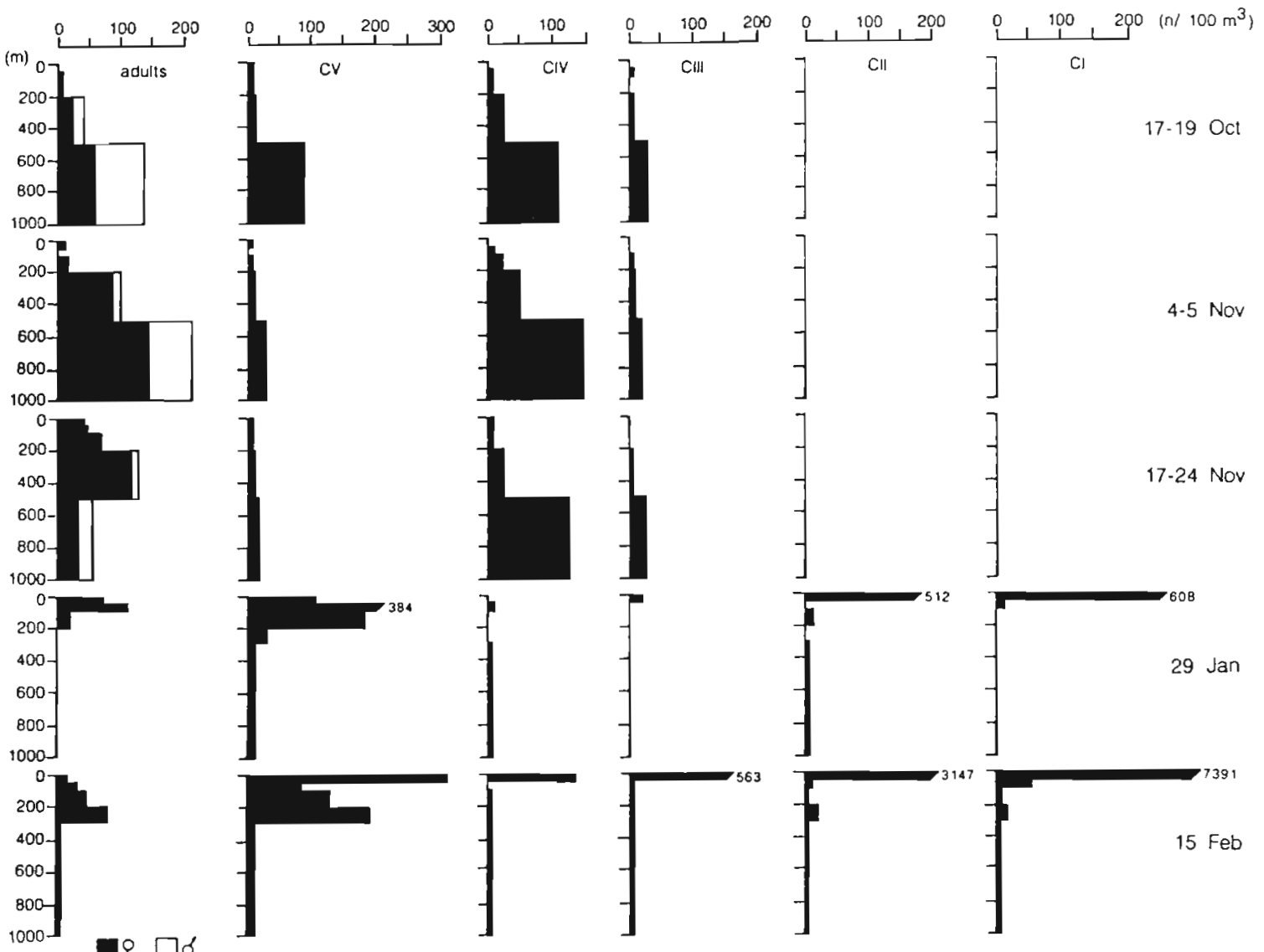

Fig. 4. Calanoides acutus. Seasonal vertical distribution pattern of copepodite stages I to $\mathrm{V}$ and adults

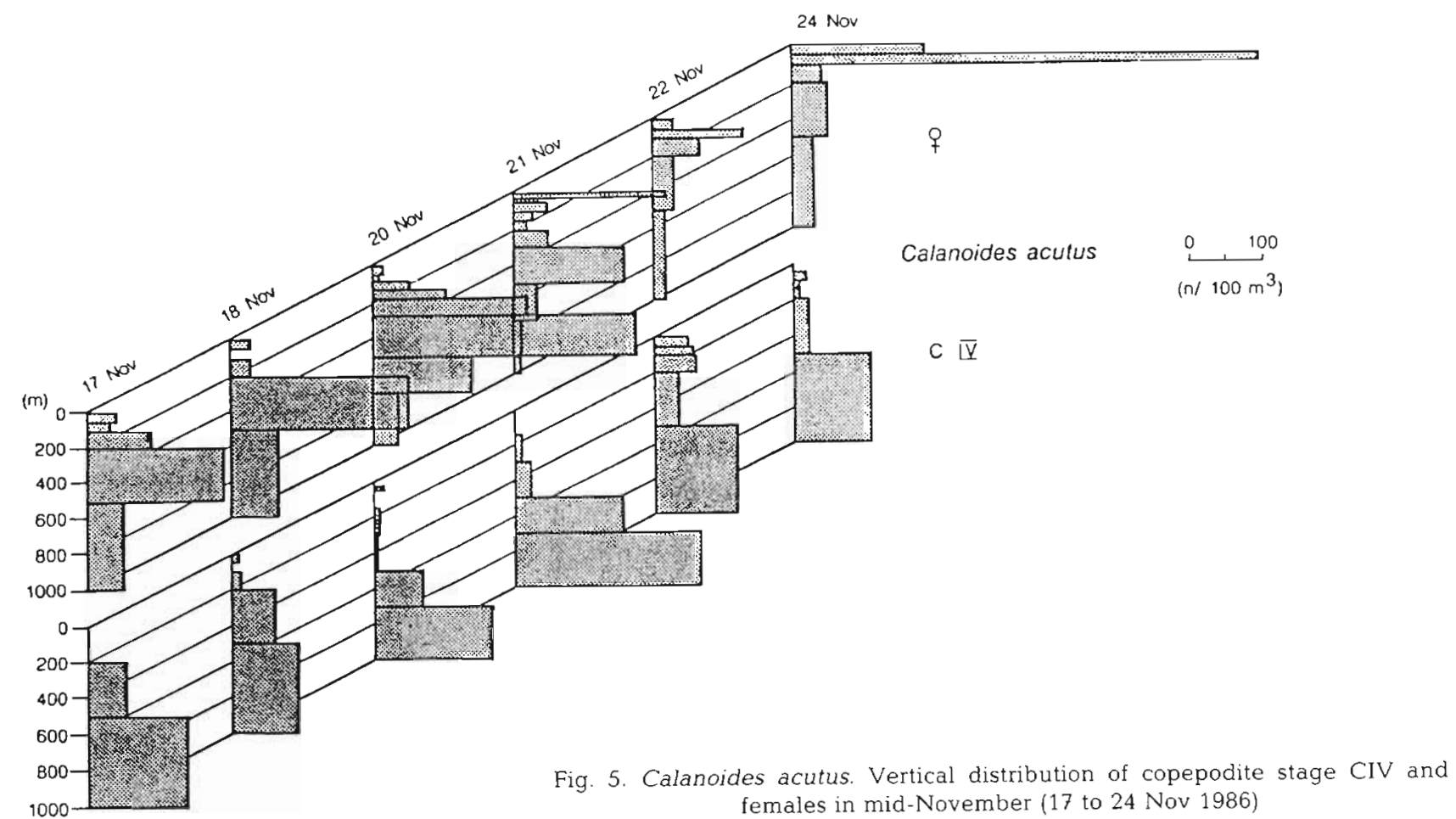




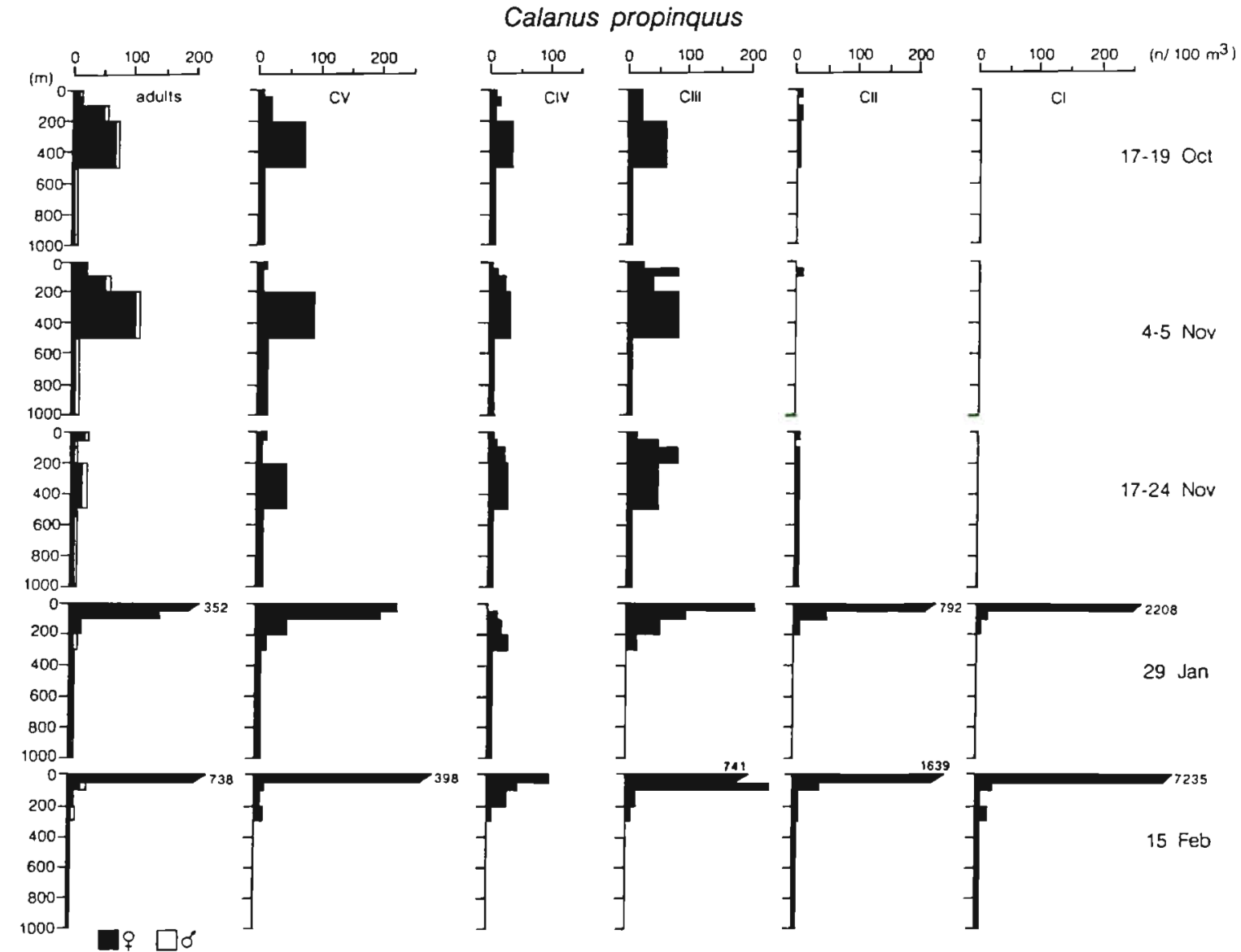

Fig. 6. Calanus propinquus. Seasonal vertical distribution pattern of copepodite stages CI-V and adults
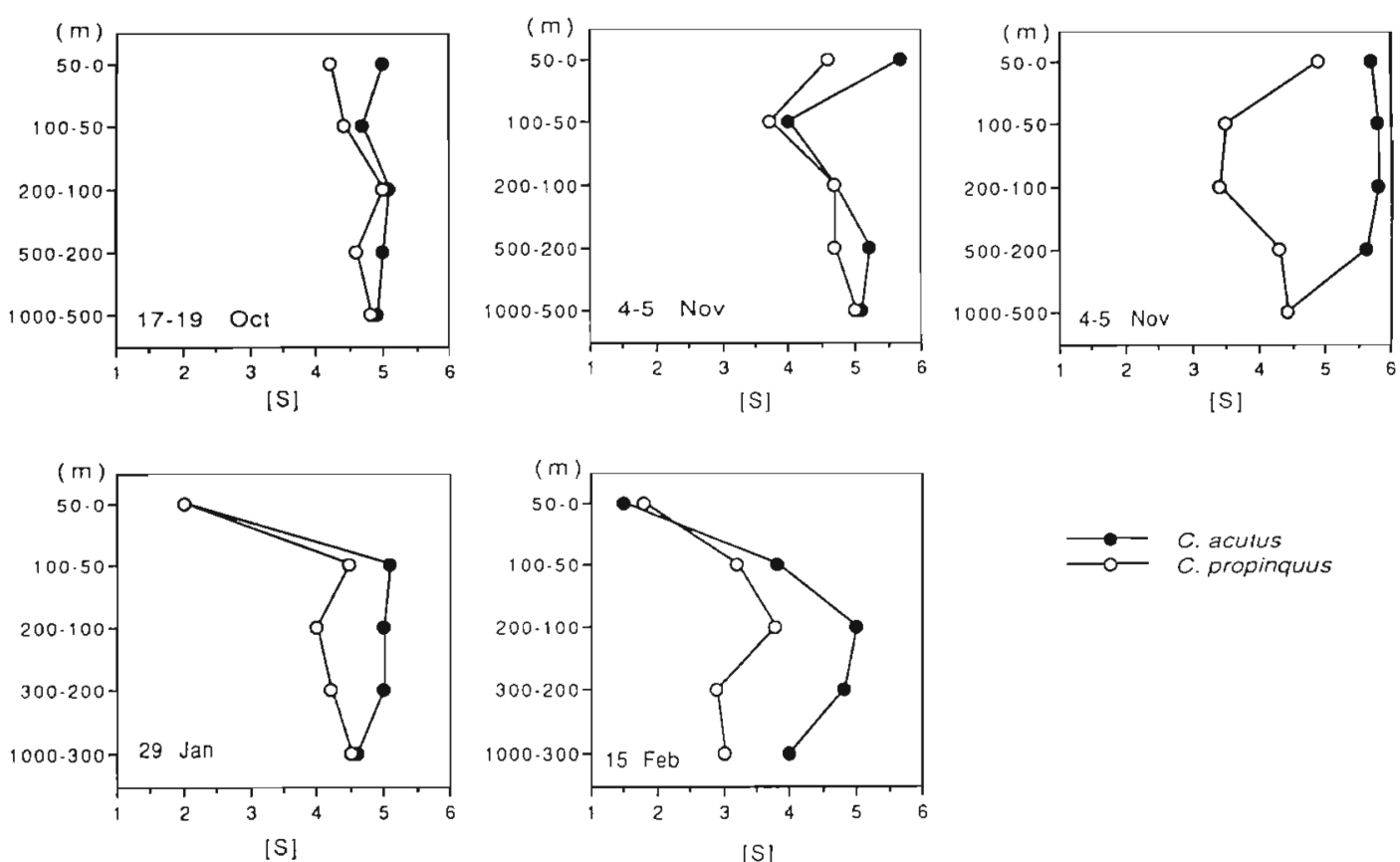

[S]

[s]

Fig. 7 Calanoides acutus and Calanus propinquus. Mean population stage $[\mathrm{S}]$ at different sampling times 
Table 2. Calanoides acutus and Calanus propinquus. Female/male ratios in the top $1000 \mathrm{~m}$. R: ratio; $\Sigma$ : sum of adults; nm: no males

\begin{tabular}{|c|c|c|c|c|c|c|c|c|c|c|c|}
\hline \multirow{2}{*}{$\begin{array}{l}\text { Depth } \\
(\mathrm{m})\end{array}$} & \multicolumn{2}{|c|}{$17-19$ Oct } & \multicolumn{2}{|c|}{ 4-5 Nov } & \multicolumn{2}{|c|}{$17-24$ Nov } & \multirow{2}{*}{$\begin{array}{l}\text { Depth } \\
\text { (m) }\end{array}$} & \multicolumn{2}{|c|}{29 Jan } & \multicolumn{2}{|c|}{15 Feb } \\
\hline & $\mathrm{R}$ & $\Sigma$ & $\mathrm{R}$ & $\Sigma$ & $\mathrm{R}$ & $\Sigma$ & & $\mathrm{R}$ & $\Sigma$ & $\mathrm{R}$ & $\Sigma$ \\
\hline \multicolumn{12}{|c|}{ Calanoides acutus } \\
\hline $0-50$ & - & 0 & $\mathrm{~nm}$ & 8 & $\mathrm{~nm}$ & 41 & $0-50$ & $\mathrm{~nm}$ & 72 & $\mathrm{~nm}$ & 3 \\
\hline $50-100$ & 1.0 & 4 & - & 0 & $\mathrm{~nm}$ & 45 & $50-100$ & $\mathrm{~nm}$ & 112 & $\mathrm{~nm}$ & 76 \\
\hline $100-200$ & $\mathrm{~nm}$ & 3 & $\mathrm{~nm}$ & 13 & 22.0 & 69 & $100-200$ & $\mathrm{~nm}$ & 20 & $\mathrm{~nm}$ & 45 \\
\hline $200-500$ & 2.6 & 32 & 31.3 & 97 & 60.0 & 122 & $200-300$ & - & 0 & $\mathrm{~nm}$ & 29 \\
\hline $500-1000$ & 0.9 & 127 & 2.2 & 207 & 2.1 & 52 & $300-1000$ & $\mathrm{~nm}$ & 2 & $\mathrm{~nm}$ & 15 \\
\hline \multicolumn{12}{|c|}{ Calanus propinquus } \\
\hline $0-50$ & 6.0 & 14 & $\mathrm{~nm}$ & 25 & 13.5 & 29 & $0-50$ & $\mathrm{~nm}$ & 352 & 105.3 & 744 \\
\hline $50-100$ & $\mathrm{~nm}$ & 16 & $\mathrm{~nm}$ & 23 & 6.0 & 7 & $50-100$ & $\mathrm{~nm}$ & 144 & 1.9 & 29 \\
\hline $100-200$ & 53.0 & 54 & 19.7 & 62 & 2.0 & 6 & $100-200$ & $\mathrm{~nm}$ & 12 & 3.0 & 8 \\
\hline $200-500$ & 11.8 & 77 & 18.3 & 116 & 7.0 & 24 & $200-300$ & 1.0 & 8 & 1.0 & 4 \\
\hline $500-1000$ & 4.0 & 5 & 1.5 & 10 & 0.8 & 7 & $300-1000$ & 2.0 & 3 & 1.0 & 2 \\
\hline
\end{tabular}

October in the 1000 to $500 \mathrm{~m}$ depth layer (female/male ratio: 0.9). Between 500 and $200 \mathrm{~m}$ in mid-October and between 1000 and $500 \mathrm{~m}$ in November the female/male ratio of C. acutus was also rather low (2.1 to 2.6).

\section{Feeding and respiration experiments}

In October and the beginning of November no feeding was detected in females and copepodite stage CV of both species at naturally occurring phytoplankton

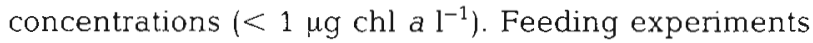
with specimens collected later in the season $(28$ November) and with enriched food supplies (10 to $40 \mu \mathrm{g} \mathrm{chl} \mathrm{a}{ }^{-1}$ ) - as can be found in the under-ice water layer on the shelf south of $74^{\circ} \mathrm{S}$ (Scharek 1990) showed that both species were actively feeding on phytoplankton (Fig. 8). Large amounts of eggs were detected under the microscope, produced by each of the 2 species at chlorophyll a concentrations exceeding $15 \mu \mathrm{g} \mathrm{I}^{-1}$

Calanoides acutus females could be divided into 3 categories according to swimming behaviour and thus, oxygen consumption: non-active (the majority in midOctober), active (the majority in early November) and very active (the majority in mid-November) (Table 3 ). From October towards November their respiration rates were increasing. A slight increase was also found for the respiration rates of Calanus propinquus, although in this species no differences in swimming activity of females were observed.

At the end of January both species were feeding on ambient phytoplankton concentrations below $1 \mu \mathrm{g}$ chl $a \mathrm{l}^{-1}$. Only small differences in clearance rates (expressed as $\mathrm{ml} \mathrm{mg}^{-1} \mathrm{DW}$ ) were found between developmental stages of Calanus propinquus. There was, how-
Fig. 8. Calanoides acutus and Calanus propinquus. Clearance rates of copepodite stage $\mathrm{CV}$ and females at different chlorophyll a concentrations in late winter/early spring 1986
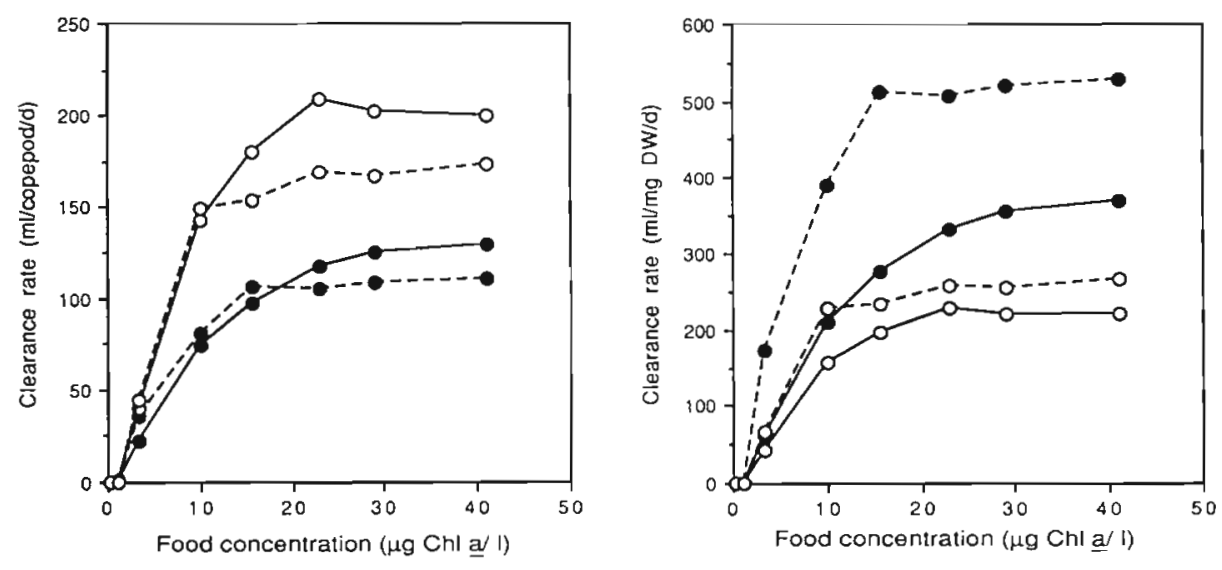
Table 3. Calanoides acutus and Calanus propinquus. Respiration rates in late winter/early spring

\begin{tabular}{|c|c|c|c|c|c|c|c|}
\hline & \multirow{2}{*}{$\begin{array}{l}\text { Dry weight } \\
\left.\text { (mg cop. }{ }^{-1}\right)\end{array}$} & \multicolumn{3}{|c|}{ ul $\mathrm{O}_{2} \operatorname{cop}^{-1} \mathrm{~h}^{-1}$} & \multicolumn{3}{|c|}{ ul $\mathrm{O}_{2} \mathrm{mg}^{-1} \mathrm{DW} \mathrm{h}^{-1}$} \\
\hline & & $21 \mathrm{Oct}$ & 2 Nov & 26 Nov & $21 \mathrm{Oct}$ & $2 \mathrm{Nov}$ & 26 Nov \\
\hline \multicolumn{8}{|l|}{ Calanoides acutus } \\
\hline $\mathrm{CV}$ & 0.21 & - & -- & 0.38 & - & - & 1.81 \\
\hline Fem. (non-active) & 0.49 & 0.10 & - & - & 0.20 & - & - \\
\hline Fem. (active) & 0.49 & 0.34 & 0.40 & 0.43 & 0.69 & 0.82 & 0.88 \\
\hline Fem. (very active) & 0.49 & - & 0.63 & 0.65 & - & 1.29 & 1.33 \\
\hline \multicolumn{8}{|c|}{ Calanus propinquus } \\
\hline $\mathrm{CV}$ & 0.69 & - & 0.47 & 0.78 & & 0.68 & 1.13 \\
\hline Fern. & 1.07 & - & 1.00 & 1.05 & - & 0.93 & 0.98 \\
\hline
\end{tabular}

ever, a pronounced decrease in feeding activity with increasing development in Calanoides acutus CIII to CV (Table 4).

\section{Lipid content and composition}

No significant differences in the lipid content of copepodite stage CV of Calanoides acutus were found between January and February (Fig. 9). The analyzed specimens had high lipid depots at the end of January as well as in February $(>42 \%$ DW). The lipids consisted mainly of wax esters (92\% of total lipid; Fig. 9). At the end of January copepodite stage CV and females of Calanus propinquus had only medium lipid contents of about $25 \%$ DW. Within 2 to $3 \mathrm{wk}$ these values rose to $47 \%(\mathrm{CV})$ and $43 \%$ (females). Early

Table 4. Calanoides acutus and Calanus propinquus. Clearance rates of different copepodite stages in late January at ambient chlorophyll concentrations $\left(0.54\right.$ to $\left.0.98 \mu \mathrm{l} \mathrm{chl} \mathrm{a} \mathrm{I}^{-1}\right)$

\begin{tabular}{|c|c|c|c|c|c|c|}
\hline & $\begin{array}{l}\text { Dry weight } \\
\text { (mg cop. }^{-1} \text { ) }\end{array}$ & $\begin{array}{l}\text { Calanoides acuth } \\
\qquad \mathrm{ml} \mathrm{cop} .^{-1} \mathrm{~d}^{-1}\end{array}$ & $\mathrm{ml} \mathrm{mg^{-1 }} \mathrm{DW} \mathrm{d}$ & $\begin{array}{l}\text { Dry weight } \\
\text { (mg cop }{ }^{-1} \text { ) }\end{array}$ & $\begin{array}{l}\text { Calanus propinquus } \\
\text { ml cop. }{ }^{-1} \mathrm{~d}^{-1}\end{array}$ & $\mathrm{ml} \mathrm{mg}{ }^{-1} \mathrm{DW} \mathrm{d}^{-1}$ \\
\hline CIII & $0.20^{\mathrm{a}}$ & 74.1 & 370.5 & 0.24 & 67.2 & 275.4 \\
\hline CIV & $0.40^{\mathrm{a}}$ & 101.5 & 255.0 & $0.49^{\mathrm{a}}$ & 122.5 & 250.0 \\
\hline $\mathrm{CV}$ & 0.85 & 65.3 & 76.8 & 0.95 & 282.4 & 298.2 \\
\hline Fem. & 1.06 & 109.2 & 103.1 & 1.60 & 337.0 & 211.0 \\
\hline Male & - & - & - & 1.02 & 188.2 & 184.5 \\
\hline
\end{tabular}

C. acutus

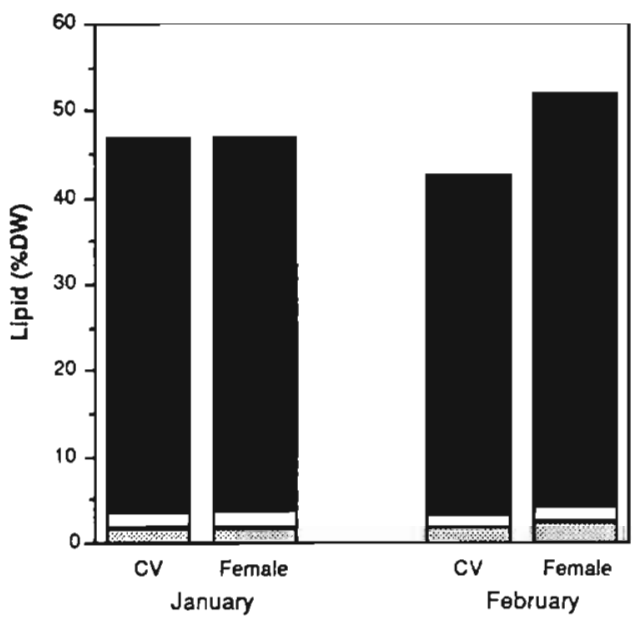

C. propinquus

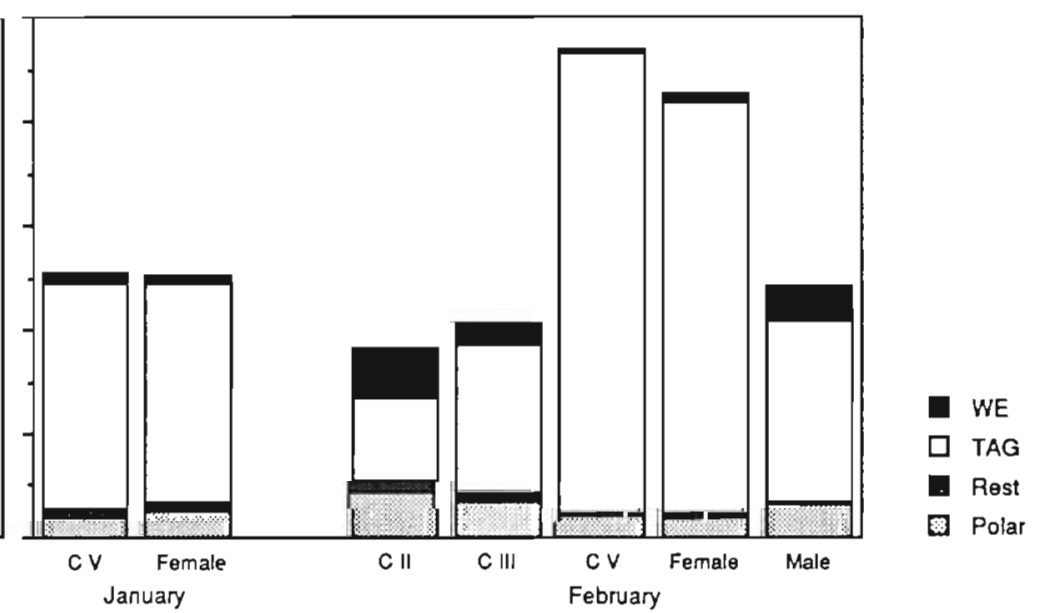

Fig. 9. Calanoides acutus and Calanus propinquus. Lipid content and composition in summer 1985. WE: wax esters; TAG: triacylglycerols; Polar: polar lipids 
stages CII and CIII and males contained relatively little lipid in February: 18, 21 and $24 \%$, respectively. All stages stored predominantly triacylglycerols (Fig. 9).

\section{DISCUSSION}

Our results from the southeastern Weddell Sea clearly demonstrate that Calanoides acutus and Calanus propinquus - mainly early copepodite stages are concentrated in the surface layers $(50$ to $0 \mathrm{~m})$ in summer, whereas older stages inhabit deeper water layers $(1000$ to $500 \mathrm{~m}:$ C. acutus; 500 to $100 \mathrm{~m}$ : C. propinquus) in winter/spring. This is in agreement with previous descriptions (e.g. Ottestad 1932, 1936, Andrews 1966, Voronina 1972). According to Andrews (1966) the ascent of $C$. acutus in circumpolar waters starts in October, and the population began to appear in deep water layers in February/March. In the Drake Passage the descent of $C$. acutus overwintering stages occurred by late March (Huntley \& Escritor in press). In the northern Weddell Sea Hopkins \& Torres (1988) found the $C$. propinquus population in March in the upper $150 \mathrm{~m}$, whereas most of the $C$. acutus population was located below $300 \mathrm{~m}$. This indicates that winter descent had already started. Our data suggest that the upward migration was delayed in high Antarctic waters by about 1 mo to mid-November, whereas the descent of $C$. acutus in mid-February did not show a delay as compared to the more northerly regions.

According to Voronina $(1972,1978)$, Calanoides acutus first ascends to the surface in spring and descends again to deeper water layers in autumn. Calanus propinquus is thought to follow the same pattern a little later in season. Consequently, in the same water masses the $C$. acutus population should be more advanced than the $C$. propinquus population (Vladimirskaya 1978, 1979, Voronina 1978, Nakamura et al. 1982, Chojnacki \& Weglenska 1984). In the southeastern Weddell Sea in late winter/early spring the $C$. acutus population consisted of older developmental stages than the $C$. propinquus population, especially in mid-November. In summer this was also true below $50 \mathrm{~m}$ depth, but no difference in the mean population stage could be observed in the top $50 \mathrm{~m}$ of the water column where the bulk of the population was concentrated, dominated by the new generation.

No Calanoides acutus males were found in January and February, but in late winter/early spring males made up 5 to $18 \%$ of the whole population. Their occurrence was almost exclusively confined to the layer between 1000 and $500 \mathrm{~m}$, which is in agreement with Vladimirskaya (1978, 1979) and Marin (1988). These males have reduced mouthparts (Vervoort 1951, Brad- ford 1988, Schnack-Schiel unpubl.) indicating their short life span. Hence, males may occur in deep water layers only for a short period of time during winter/ early spring when mating and fertilization takes place. This is supported by the ascent of fertilized females in mid-November in the Weddell Sea and confirms the results found by Marin (1988). On the other hand, males of Calanus propinquus were not restricted to the deeper water layers and occurred at all seasons investigated. Their mouthparts were well-developed. This indicates a more extended longevity and thus a prolonged fertilization period. This is in agreement with Fransz (1988) who found C. propinquus from eggs to adults in October/November in the upper $200 \mathrm{~m}$, whereas eggs and nauplii of $C$. acutus were not present before the end of November.

In October/early November there was practically no phytoplankton in the water column (Gieskes et al. 1987), but the ascent of Calanoides acutus females in mid-November coincided with the onset of sea-ice melting and a subsequent slight increase of chlorophyll $a$ in the water column $\left(0.01-0.02\right.$ to $0.1-0.2 \mu \mathrm{g} 1^{-1}$; Scharek 1990)

These distributional differences are supplemented by our experimental and biochemical data, which also indicate physiological differences. In early spring (October) older stages of both species did not feed on the ambient phytoplankton concentrations of the water column $\left(<1 \mu \mathrm{g} \mathrm{chl} \mathrm{a} \mathrm{l}^{-1}\right)$, although at the end of January feeding occurred below these concentrations. However, clearance rates in the Weddell Sea were about 3 to 4 times lower than in November/December 1980 in the Drake Passage at similar chlorophyll concentrations (Schnack et al. 1985). In the high Antarctic Ross Sea in February gut content analyses showed that both species were still feeding (Hopkins 1985). Near the Antarctic Peninsula in March/April Calanoides acutus had ceased feeding, whereas half of the Calanus propinquus population had food in their guts (Hopkins 1987). In the Antarctic Peninsula region there were no great differences in feeding behaviour of C. acutus and C. propinquus in November/ December 1980 and February 1982 apart from one station close to the ice edge, where $C$. acutus seemed to be in overwintering condition with relatively low feeding activities (Schnack 1985). At open-water stations in the northern Weddell Sea in March, C. acutus and $C$. propinquus had mainly phytoplankton in their guts. Within the pack ice, however, C. propinquus had ingested a significantly larger proportion of metazoans (mainly cyclopoid copepods), whereas C. acutus, which only occurred below $200 \mathrm{~m}$, had empty guts (Hopkins \& Torres 1989).

In the Weddell Sea both species increased their respiration rate during spring and Calanoides acutus 
changed from non-active to very active swimming behaviour within weeks, as expected when awakening from diapause. Calanus propinquus was active throughout this period. The oxygen consumption values determined in this study fit well into the range of previous data (Ikeda \& Mitchell 1982, Schnack et al. 1985). Extremely low oxygen consumption rates were published by Hirche (1984) for C. acutus CV $(0.086 \mu l$ $\mathrm{O}_{2} \mathrm{mg}^{-1} \mathrm{DW} \mathrm{h}^{-1}$ ) from the northwestern Weddell Sea in February, probably due to overwintering conditions (diapause) of the specimens.

Furthermore, there are striking differences in the lipid data. The lipid stores of older stages of Calanoides acutus (CV, females) had already reached maximum lipid contents in January, whereas Calanus propinquus $\mathrm{CV}$ stages and females almost doubled their lipid depots from January to February. Hence, they reached similar maximum lipid values at least 3 wk later than $C$. acutus. Lipids in $C$. acutus were accumulated as wax esters, whereas $C$. propinquus stored their energy as triacylglycerols. Previously, calanoid copepods from high latitudes were known to store wax esters as energy resource (Lee et al. 1973). C. propinquus is one exception from polar regions deviating from this pattern (Hagen 1988). Based on their investigations on Arctic copepods and euphausiids Sargent et al. (1981) proposed that triacylglycerols are indicators for continuous feeding. whereas wax esters suggest long periods of starvation (Lee \& Hirota 1971, Sargent et al. 1981, Sargent \& Henderson 1986). Like C. propinquus, the Antarctic krill Euphausia superba is rich in triacylglycerols but wax-ester-deficient (Clarke 1984, Hagen 1988) and underwater observations revealed $E$. superba living in pack ice crevices during winter/early spring and feeding extensively on ice algae (Daly \& Macaulay 1988, Marschall 1988, Stretch et al. 1988). It is unknown whether $C$. propinquus can also utilize this food source. Hopkins' \& Torres' (1989) data from the northern Weddell Sea indicate feeding of C. propinquus and E. superba in March on metazoans.

In summary, our data suggest that both copepod species follow different modes of life ('strategies') as adaptations to the pronounced Antarctic seasonality. Calanoides acutus seems to descend to deeper water layers, cease feeding and overwinter in a resting stage (diapause) to save energy during the starvation period. In spring it is the first species to ascend and the females make use of their remaining wax ester reserves to produce offspring. Calanus propinquus also descends to mesopelagic waters, but not as deep as $C$. acutus and may overwinter without diapause period. Their spawning period is not restricted to the spring season and small numbers of young stages (CII) are also present when food is scarce. During these periods $C$ propinquus can utilize their large triacylglycerol reserves or may switch to carnivorous feeding.

Acknowledgements. We thank Drs U. Bathmann, T L. Hopkins and G. Hubold for critically reading the manuscript. W. $H$. is very much indebted to Prof. J. R. Sargent and his team for introducing him to the methods of lipid analysis. This is contribution no. 317 of the Alfred-Wegener-Institut für Polarund Meeresforschung, Bremerhaven, Germany.

\section{LITERATURE CITED}

Andrews, K. J. H. (1966). The distribution and life history of Calanoides acutus (Giesbrecht). 'Discovery' Rep. 34: $117-162$

Bămstedt, U. (1986). Chemical composition and energy content. In: Corner, E. D. S., O'Hara, S. C. M. (eds.) Biological chemistry of marine copepods. Clarendon Press, Oxford, p. $1-58$

Boysen-Ennen, E., Piatkowski, U. (1988). Meso- and macrozooplankton communities in the Weddell Sea. Polar Biol. 9: $17-35$

Bradford, J. M. (1988). Review of the taxonomy of the Calanidae (Copepoda) and the limits to the genus Calanus. Hydrobiologia 167/168: 73-81

Chojnacki, J., Weglenska, T. (1984). Periodicity of composition, abundance, and vertical distribution of summer zooplankton (1977/78) in Ezcurra Inlet, Admiralty Bay (King George Island, South Shetland). J. Plankton Res. 6: 997-1017

Clarke, A. (1984). Lipid content and composition of Antarctic krill, Euphausia superba Dana. J. Crust. Biol. 4: 285-294

Daly, K. L., Macaulay, M. C. (1988). Abundance and distribution of krill in the ice edge zone of the Weddell Sea, austral spring 1983. Deep Sea Res. 35: 21-41

Folch, J., Lees, M., Sloane-Stanley, G. H. (1957). A simple method for the isolation and purification of total lipids from animals tissues. J. biol. Chem. 226: 496-509

Fransz, H. G. (1988). Vernal abundance, structure and development of epipelagic copepod populations of the eastern Weddell Sea (Antarctica). Polar Biol. 9: 107-114

Fraser, A. J., Tocher, D. R., Sargent, J. R. (1985). Thin-layer chromatography - flame ionization detection and the quantitation of marine neutral lipids and phospholipids. J. exp. mar. Biol. Ecol. 88: 91-100

Frost, B. W. (1972). Effects of size and concentration of food particles on the feeding behavior of the marine planktonic copepod Calanus pacificus. Limnol. Oceanogr. 17: $805-815$

Gieskes, W. W. C., Veth, C., Wöhrmann, A., Gräfe, M. (1987). Secchi disc depth visibility world record shattered. EOS 68: 123

Hagen, W. (1988). Zur Bedeutung der Lipide im antarktischen Zooplankton. Ber. Polarforsch. 49: 1-129

HempeI, G. (1985). Die Expedition Antarktis III mit FS 'Polarstern' 1984/85. Ber. Polarforsch. 25: 1-209

Hirche, H.-J. (1984). Temperature and metabolism of plankton. - I. Respiration of Antarctic zooplankton at different temperatures with a comparison of Antarctic and nordic krill. Comp. Biochem. Physiol. 74 A: 361-368

Hopkins, T. L. (1985), Food web of an Antarctic midwater ecosystem. Mar. Biol. 89: 197-212 
Hopkins, T L. (1987). Midwater food web in McMurdo Sound, Ross Sea, Antarctica. Mar Biol, 96: 93-106

Hopkins, T L., Torres, J. J. (1988). The zooplankton community in the vicinity of the ice edge, western Weddell Sea, March 1986. Polar Biol. 9: 79-87

Hopkins, T L., Torres, J. J. (1989). Midwater food web in the vicinity of a marginal ice zone in the western Weddell Sea. Deep Sea Res. 36: 543-560

Hubold, G., Hempel, I. (1987). Seasonal variability of zooplankton in the southern Weddell Sea. Meeresforschung 31: $185-192$

Huntley, M., Escritor, F. (in press). Dynamics of Calanoides acutus (Copepoda: Calanoida) in Antarctic coastal waters. Deep Sea Res.

Ikeda, T., Mitchell, A. W. (1982). Oxygen consumption, ammonia excretion and phosphate excretion by krill and other Antarctic zooplankton in relation to their body size and chemical composition. Mar. Biol. 71: 283-298

Kaczmaruk, B. Z. (1983). Occurrence and distribution of the Antarctic copepods along the ice shelves in the Weddell Sea in summer 1979/80. Meeresforschung 30: 25-41

Lee, R. F., Hirota, J. (1973). Wax exters in tropical zooplankton and nekton and the geographical distribution of wax esters in marine copepods. Limnol. Oceanogr. 18: 227-239

Lee, R. F., Hirota, J., Barnett, A. M. (1971). Distribution and importance of wax esters in marine copepods and other zooplankton. Deep Sea Res. 18: 1147-1165

Marschall, H. P. (1988). The overwintering strategy of Antarctic krill under the pack-ice of the Weddell Sea. Polar Biol. 9: $129-135$

Marin, V. (1988). Qualitative models of the life cycles of Calanoides acutus, Calanus propinquus and Rhincalanus gigas. Polar Biol. 8: 439-446

Nakamura, M., Kadota, S., Fukuchi, M. (1982). Epipelagic copepods of Calanoida in the Indian sector of the Antarctic Ocean. Mem. natn. Inst. polar Res. Tokyo 23: 28-31

Ottestad, P. (1932). On the biology of some southern copepods. Hvalråd. Skr. 5: 1-61

Ottestad, P. (1936). On Antarctic copepods from the 'Norvegia' expedition 1930-1931. Scientific Results of the Norwegian Antarctic Expeditions 1927-1928 et SQQ. 15: 1-44

Runge, J. A. (1985). Relationship of egg production of Calanus pacificus to seasonal changes in phytoplankton availability in Puget Sound, Washington. Limnol. Oceanogr. 30: 382-396

Sargent, J. R., Gatten, R. R., Henderson, R. J. (1981). Lipid biochemistry of zooplankton from high latitudes. Oceanis 7: $623-632$

This article was submitted to the editor
Sargent, J. R., Henderson, R. J. (1986). Lipids. In: Corner, E. D. S., O'Hara, S. C. M. (eds.) The biological chemistry of marine copepods. Clarendon Press, Oxford, p. 59-108

Scharek, R. (1990). Die Entwicklung des Phytoplanktons im östlichen Weddellmeer (Antarktis) beim Übergang vom Spätwinter zum Frühjahr. Ph.D. thesis, University of Bremen

Schnack, S. B. (1985). Feeding by Euphausia superba and copepod species in response to varying concentrations of phytoplankton. In: Siegfried, W R., Condy, P. R., Laws, R. M. (eds.) Antarctic nutrient cycles and food webs. Springer-Verlag, Berlin, p. 311-323

Schnack-Schiel, S. B. (1987). The winter expedition of RV 'Polarstern' to the Antarctic (ANT V/1-3). Ber. Polarforsch. 39: $1-159$

Schnack, S. B., Smetacek, V., Bodungen, B. von, Stegmann, P. (1985). Utilization of phytoplankton by copepods in Antarctic waters during spring. In: Gray, J. S., Christiansen, M. E. (eds.) Marine biology of polar regions and effects of stress on marine organisms. John Wiley \& Sons, Chichester, p. 65-81

Stretch, J. J., Hamner, P. P., Hamner, W. M., Michel, W. C., Cook, J, Sullivan, C. W. (1988). Foraging behavior of Antarctic krill Euphausia superba on sea ice microalgae. Mar. Ecol. Prog. Ser. 44: 131-139

Vervoort, W. (1951). Plankton copepods from the Atlantic sector of the Antarctic. Verh. K. Ned. Akad. Wet., Aid. Natuurkunde 37: 1-156

Vladimirskaya, Ye. V. (1978). Age composition of winter population of abundant copepod species in the southern part of the Scotia Sea. Oceanology 18: 202-204

Vladimirskaya, Ye. V (1979). Winter distribution of mass species of copepods in the southern part of Scotia Sea. Sov. J. mar. Biol. 5: 463-468

Voronina, N. M. (1972). Vertical structure of a pelagic community in the Antarctic. Oceanology 12: 415-420

Voronina, N. M. (1978). Variability of ecosystems. In: Charnock, H., Deacon, G. E. R. (eds.) Advances in oceanography. Plenum Press, New York, p. 3221-3243

Voronina, N. M., Vladimirskaya, Ye. V., Zmiyevskaya, M. I. (1978). Seasonal variations in the age composition and vertical distribution of common zooplankton species in the Southern Ocean. Oceanology 18: 335-338

Weikert, H., John, H.-Ch. (1981). Experiences with a modified Bé multiple opening-closing plankton net. J. Plankton Res. 3: $167-176$

Manuscript first received: August 24, 1990

Revised version accepted: December 4, 1990 